\title{
Efektifitas Program Pendidikan Kesehatan Terhadap Durasi Persalinan pada Ibu Bersalin Spontan
}

\author{
Desmawati ${ }^{1}{ }$ Agustina $^{2}$ \\ ${ }^{1,2}$ Fakultas Ilmu Kesehatan, Universitas Pembangunan Nasional Veteran Jakarta \\ Jl. Limo Raya No.7, RT.2/RW.5, Limo, Kec. Limo, Kota Depok, Jawa Barat 16514 \\ E-mail: ${ }^{1}$ desmawati@upnvj.ac.id, ${ }^{2}$ syeikhayla.jabarina@gmail.com
}

\begin{abstract}
Abstrak
Durasi persalinan adalah lamanya waktu persalinan. Persalinan lama (macet) akan berdampak buruk untuk ibu dan janin. Program pendidikan bisa menfasilitasi dalam pencegahan persalinan lama dan ibu bisa bersalin secara spontan. Tujuan penelitian untuk menguji efektifitas program pendidikan kesehatan terhadap lamanya waktu bersalin pada ibu yang melahirkan spontan. Studi ini adalah rancangan quasi experimental dengan melibatkan 54 ibu bersalin spontan ( $n=27$ pada kelompok kontrol) dan $(n=27$ pada kelompok intervensi). Durasi persalinan diukur dalam menit. Program ini diberikan sejak ibu hamil 36-37 minggu sampai ibu melahirkan spontan (tidak seksio sesaria) dengan metode pengajaran, demonstrasi, follow up ibu via telepon setiap hari sampai masuk ruang bersalin dan observasi durasi persalinan di ruang bersalin. T-test digunakan untuk menganalisa data penelitian ini. Hasil menunjukkan adanya pengaruh yang signifikan program pendidikan terhadap durasi persalinan kala 2 pada ibu dengan persalinan spontan di kelompok intervensi $(t=4.152, p=0.000)$ dibanding dengan kelompok kontrol. Namun tidak ada perbedaan yang signifikan antara durasi persalinan pada fase latent $(t=0.88, p=0.383)$ dan fase aktif $(\mathrm{t}=0.358, \mathrm{p}=0.722)$ antara kelompok intervensi dan kelompok kontrol. Luaran penelitian membuktikan program ini bisa diterapkan ditatanan praktek pelayanan kesehatan dalam mempersingkat durasi persalinan kala dua.
\end{abstract}

Kata kunci: Pendidikan kesehatan, ibu bersalin, persalinan spontan, durasi persalinan

\begin{abstract}
Duration of labor is length of labor. Prolonged labor may have adverse effects on the mother and fetus. Health Education Program can facilitate to prevent prolonged labor and make natural delivery. Purpose: The purpose of this study was to examine the effect of health education on duration of second stage of labor in spontaneous delivery. Methods: A study with quasy experimental design was conducted by involving 54 primiparous women and their family by purposive sampling assignment either control group or intervention group (each group 27 participants). Outcome was measured in minutes. The program conducted from 36-37 weeks of pregnancy until laboring women with several implementation methods, such as health teaching about health program, telephone calls, demonstration, and observation. Analysis: Independent T-test was used in this study for measuring the duration of labor. Results; There was a significant effect of the health education program on the duration of second stage labor in spontaneous delivery in the intervention group $(t=4.152, p=0.000)$ compared to the control group. However, there was no significant difference between the duration of labor at the latent phase $(t=0.88, p=0.383)$ and the active phase $(t=0.358, p=0.722)$ between the intervention group and the control group. Conclusions: This study have feasible to be conducted and effective to shorten duration of labor in second stage of labor.
\end{abstract}

Keywords: Holistic Education, Spontaneous labor, Duration of labor 


\section{Pendahuluan}

Persalinan spontan adalah proses persalinan pervaginam (melalui vagina) tanpa adanya penyulit persalinan dan komplikasi ${ }^{1}$. Hasil Riskesdas Tahun 2013 menunjukkan kelahiran spontan di Indonesia sebesar 90,2\% dengan proporsi terendah di DKI Jakarta $(80,1 \%)$ dan tertinggi di Sulawesi Tenggara (96,7\%). Persalinan spontan merupakan hal yang alamiah. Persalinan spontan akan bisa terealisasi diantaranya karena adanya pengetahuan dan keyakinan ibu yang kuat untuk bersalin normal, posisi tegak yang bisa mempercepat penurunan kepala akibat gaya gravitasi ${ }^{2}$. Pencegahan partus lama yang berujung pada persalinan seksio sesaria, menjadi dasar bagi perawat betapa urgensi atau pentingnya untuk memberikan pendidikan kesehatan yaitu baik fisik maupun mental ${ }^{4}$.

Program Pendidikan kesehatan ini diharapkan akan membantu ibu melakukan semua yang diajarkan dalam menghadapi persalinan untuk mencegah partus lama. Kebanyakan penelitian terdahulu masih memberikan pendidikan kesehatan berorientasi kepada faktor fisik saja, sedangkan faktor lain seperti factor social budaya dan spiritual sering diabaikan ${ }^{5}$. Perbedaan penelitian ini dengan penelitian yang telah lampau tersebut adalah penelitian ini memberikan pendidikan kesehatan dalam semua factor yaitu bukan hanya fisik saja, namun juga psikososial dan sebagainya. Hasil studi pendahuluan di beberapa tempat bersalin diwilayah kerja Sawangan Depok, belum ditemukan pemberian pendidikan kesehatan dalam mempersiapkan ibu untuk persalinan spontan.

Berdasarkan uraian diatas maka efektifitas program pendidikan kesehatan terhadap durasi persalinan pada ibu-ibu yang melahirkan spontan perlu diteliti. Program pendidikan kesehatan pada penelitian ini adalah suatu program health teaching yang diberikan kepada ibu hamil trimester 3 (usia kehamilan 36-38 minggu kehamilan) dalam menghadapi persalinan normal supaya persalinan aman dan lancar. Tujuan penelitian ini untuk mengetahui keefektifan program pendidikan kesehatan terhadap durasi persalinan fase latent, fase aktif dan kala 2 pada ibu-ibu yang melahirkan normal di wilayah kerja Sawangan Depok.

\section{Metode}

Rancangan penelitian adalah quasi eksperimen dengan menggunakan rancangan two groups with posttest design, untuk menguji perubahan yang terjadi setelah adanya eksperimen (perlakuan) dengan kelompok pembanding (kelompok kontrol). Efektivitas perlakuan dinilai dengan cara membandingkan durasi persalinan latent, aktif dan kala 2 antara kelompok kontrol dengan intervensi. Jumlah sampel adalah 54 ibu melahirkan, yang dibagi menjadi 27 orang pada kelompok perlakuan dan 27 orang pada kelompok kontrol dengan purposive sampling sesuai kriteria inklusi; ibu yang berniat untuk bersalin normal, tidak ada komplikasi ibu dan janin, ibu yang mendapat dukungan/support dari keluarga, ibu bersedia menjadi responden penelitian dari awal hingga akhir, dan ibu dengan janin tunggal.

Prosedur; Ibu hamil yang memenuhi kriteria inklusi diminta untuk menjadi partisipan dengan penandatanganan informed cosent terlebih dahulu di antenatal klinik bersalin diarea kerja Sawangan Depok. Ibu hamil 36-37 minggu kehamilan diberikan pendidikan kesehatan tentang bagaimana tanda-tanda persalinan, bagaimana melakukan nafas dalam saat kontraksi uterus, bagaimana memenuhi kebutuhan spiritual dan psikologis saat bersalin seperti murotal, kebiasaan budaya yang tidak berlawanan dengan kesehatan pasien dengan pelibatan keluarga. Selain itu bagaimana melibatkan keluarga dalam perubahan posisi dan pemenuhan kebutuhan dasar pasien secara holistik. Ibu dianjurkan untuk mempraktekkan di rumah sebagai upaya persiapan bersalin nanti. Peneliti melakukan follow up via telepon 
setiap hari sampai ibu masuk ke ruang bersalin untuk melahirkan. Di ruangan bersalin, durasi persalinan dinilai dalam menit, baik untuk fase latent, fase aktif dan kala 2 persalinan.

Analisa bivariat dilakukan untuk melihat berapakah durasi persalinan fase latent, fase aktif dan kala 2 persalinan setelah diberikan program pendidikan kesehatan untuk kelompok intervensi, dan tanpa mendapatkan program untuk kelompok kontrol (hanya perawatan rutin). Uji $T$ independen dengan tingkat kemaknaan 95\% (alpha 0,05), digunakan dalam penelitian ini.

\section{Hasil}

Tabel 1. Distribusi durasi persalinan pada fase latent, fase aktif dan kala 2 pada kelompok kontrol dan intervensi

\begin{tabular}{llcccc}
\hline Durasi Persalinan & Durasi persalinan & n & Mean & SD & SE \\
\hline Fase latent & Kelompok Kontrol & 27 & 231,11 & 21,72 & 4,180 \\
& Kelompok Intervensi & 27 & 235,55 & 14,69 & 2,825 \\
Fase aktif & Kelompok Kontrol & 27 & 233,26 & 48,906 & 9,412 \\
& Kelompok Intervensi & 27 & 219,37 & 195,356 & 37,596 \\
Kala 2 & Kelompok Kontrol & 27 & 30,41 & 14,21 & 2,736 \\
& Kelompok Intervensi & 27 & 16,44 & 10,16 & 1,956 \\
\hline
\end{tabular}

Tabel 2. Analisa pengaruh pendidikan keseahatan terhadap durasi persalinan fase latent, fase aktif, dan kala 2

\begin{tabular}{lcccccc}
\hline \multicolumn{1}{c}{ Variabel } & n & Mean defference & SE defference & $\boldsymbol{t}$ & df & P Value \\
\hline Durasi pesalinan fase latent & 54 & -4.44 & 5.04 & -0.88 & 52 & 0,383 \\
Durasi pesalinan fase aktif & 54 & 13.88 & 38.75 & 0.358 & 52 & 0,722 \\
Durasi pesalinan kala 2 & 54 & 13.96 & 3.363 & 4.152 & 52 & 0,000 \\
\hline
\end{tabular}

Berdasarkan Tabel 1. rata-rata lamanya persalinan pada fase latent adalah 235.55 menit pada kelompok perlakuan dan 231.11 menit pada kelompok kontrol. Rata-rata lamanya persalinan pada fase aktif adalah 233.26 menit pada kelompok perlakuan dan 219.37 menit pada kelompok kontrol. Rata-rata lamanya persalinan pada kala 2 adalah 30.41 menit pada kelompok perlakuan dan 16.44 menit pada kelompok kontrol.

Tidak ada perbedaan yang signifikan antara lama persalinan fase latent pada kelompok perlakuan dengan kelompok kontrol ( $t=-0.88, p-0.383)$. Tidak ada perbedaan yang signifikan antara lama persalinan fase aktif pada kelompok perlakuan dengan kelompok kontrol $(t=$ $0.358, p-0.722)$. Terdapat perbedaan yang signifikan antara lama persalinan fase aktif pada kelompok perlakuan dengan kelompok kontrol ( $t=4.152, p=0.000)$ (Tabel 2).

\section{Pembahasan}

Penelitian ini menemukan hasil yang signifikan bahwa pendidikan kesehatan bisa mempercepat durasi persalinan kala 2 persalinan ( $t=4.152, p=0.000)$, namun tidak bisa mempercepat durasi persalinan kala 1 baik fase latent maupun fase aktif persalinan. Hal ini karena materi pendidikan holistik yang diberikan hanya dikhususkan untuk kala 2 persalinan seperti mengelola nyeri persalinan nonfarmakologik dengan stroking, nafas dalam, pelibatan keluarga, intervensi spiritual dan kultural.

Selain itu pendidikan keseahatan juga bisa meningkatkan Apgar score pada menit 1 dan 5. Belum ditemukan penelitian sebelumnya yang melaporkan bahwa pendidikan holistik bisa mempercepat 
durasi persalinan kala 1 persalinan, namun ada penelitian yang melaporkan bahwa pendidikan terkait persiapan persalinan yang diberikan kepada ibu hamil dan dipraktikkan saat melahirkan bisa menurunkan nyeri persalinan pada pembukaan servik 3-4 $\mathrm{cm}$ dan 7-8 $\mathrm{cm}^{6-8}$ Demikian juga penelitian Firouzbakht $\mathrm{dkk}^{6}$ melaporkan bahwa pendidikan terkait perinatal dan diaplikasikan saat bersalin dapat menurunkan nyeri persalinan pada fase aktif persalinan $(\mathrm{p}=0.03)$, namun tidak signifikan untuk masa peralihan fase latent ke fase aktif persalinan dan kala 2 persalinan. Penelitian sebelumnya juga melaporkan bahwa persalinan fisiologi terbukti menurunkan nyeri pada dilatasi servik $3-4 \mathrm{~cm}$ dan 7-8 $\mathrm{cm} \quad(\mathrm{p}=0.001){ }^{6,7} \quad$ Penelitian lain melaporkan dengan hanya terapi spiritual yaitu murotal Quran bisa menurunkan nyeri dan kecemasan ibu bersalin fase aktif kala 1 persalinan. ${ }^{10,11}$ Dilaporkan juga bahwa terapi music bisa menurunkan nyeri post seksio sesaria, begitu juga walaupun hanya mendengarkan saja. ${ }^{10,11}$ Berdo'a bisa menurunkan nyeri dan mencegah partus lama. $^{12}$

Banyak faktor yang mempengaruhi kecepatan waktu melahirkan seseorang, diantaranya posisi ibu saat mulainya tandatanda persalinan sampai plasenta lahir, faktor psikologis pasien, nutrisi ataupun daya mengedan ibu. Selain Pendidikan kepada ibu ${ }^{13}$, etnik dan kebiasaan ibu dan keluarga juga mempengaruhi seseorang berperilaku dalam menghadapi persalinan dan durasi persalinan ${ }^{14}$. Pendampingan keluarga sangat memberikan manfaat yang positif terhadap keadaan psikologis klien dalam mempercepat waktu bersalin. Hasil penelitian ini, juga didukung oleh penelitian Shakeri ${ }^{10}$, yang melaporkan kelompok intervensi dengan materi persalinan fisiologik dapat mengurangi angka kejadian seksio sesaria dan meningkatkan kesehatan ibu secara keseluruhan.

Walaupun pendidikan kesehatan ini sudah terbukti bisa mempercepat durasi bersalin kala 2 yaitu kala pengeluaran bayi atau kelahiran bayi, namun masih banyak keterbatasan yang ditemukan, diantaranya; kurangnya dukungan keluarga saat kala 1 baik fase latent dan fase aktif persalinan, karena masalah psikologis ibu sangat berdampak dengan waktu persalinan. Untuk hal tersebut pengumpulan data kualitatif sangat disarankan dalam memperkaya factor penyebab lain yang bisa mempercepat durasi persalinan.

\section{Kesimpulan}

Hasil penelitian ini menunjukkan bahwa pendidikan kesehatan berpengaruh terhadap singkatnya waktu bersalin kala 2 persalinan, namun tidak berefek keapada penurunan waktu persalinan kala 1 baik fase latent maupun fase aktif persalinan karena materi pendidikan kesehatannya hanya fokus pada asuhan keperawatan pada kala 2 persalinan. Namun hal ini bisa berdampak positif kepada menurunnya angka kejadian seksio sesarea cyto (segera). Program ini sudah dinyatakan aman dan nyaman diaplikasikan ke partisipan, tidak membahayakan bagi ibu dan janin. Selain itu program ini juga simpel dan tidak membebani pasien saat melakukannya, justru sebaliknya sangat membantu pasien dalam menghadapi masalah kehamilan dan persalinan. Dianjurkan untuk menerapkan program ini disemua tatanan kesehatan yang memberikan pelayanan kepada ibu hamil dan melahirkan.

Adapun saran terkait keterbatasan diatas, 1) dilanjutkan dengan penelitian besar yang membutuhkan tenaga, waktu dan biaya yang besar, yaitu dimulai dari trimester 2-3 kehamilan, 2) program pendidikan holistiknya ditambah untuk fase laten, aktif dan kemudian juga bisa dilanjutkan kala 3 persalinan (untuk persalinan normal), 3) dan juga dilanjutkan saat operasi bagi yang seksio sesarea, karena telinga mereka masih mendengar dan hati mereka masih bisa berkata, walaupun dalam kondisi pembiusan operasi mereka masih bisa berdoa berzikir 
dan lainnya dengan Allah SWT, 4) dimaksimalkan data penelitiannya dengan study kualitatif karena pengalaman selama hamil dan bersalin adalah subyektif dan unik, terakhir 5) dalam pencapaian SDGs untuk mengurangi angka kematian ibu dan bayi di Indonesia, seyogyanyalah program juga diberikan kepada ibu multigravidamultipara (semua ibu hamil dan bersalin) diseluruh Indonesia.

\section{Daftar Pustaka}

1. Alexander JM. Obstetric Emergencies, An Issue of Obstetrics and Gynecology Clinics 2013; 40 (1). Elsevier Health Sciences.

2. Asmadi. Teknik prosedural keperawatan: konsep dan aplikasi kebutuhan dasar klien. Jakarta: Salemba Medika; 2008.

3. Desmawati. Effect of $d o^{\prime} a$ on pain-coping behaviors of Muslim women during the first three hours of the active phase of labor. Belitung Nursing Journal 2016; 2(5), 99-106.

4. Ebirim LN, Buowari OY, \& Ghosh S. Physical and psychological aspects of pain in obstetrics, 2012; Chapter 9. p.219-236. Retrieved from http://dx.doi.org/10.5772/53923. cdn.intechopen.com

5. Faradisi F. Effect of murotal Qur'an therapy and classic musical on level anxiety and pain in preoperative patients at Pekalongan. Journal of Health Science 2012; 5(2), 1-11.

6. Firouzbakht, Nikpour, Salmalian, Ledari, Khafri. The effect of perinatal education on
Iranian mothers' stress and labor pain, Global Journal of Health Science 2014; 6(1), 61-68

7. Handayani R. Pengaruh pemberian terapi musik terhadap nyeri pasien post op seksio sesaria (SC) di RS Eka Hospital BSD. Jurnal Ilmiah Kesehatan Keperawatan 2014; 9 (2).

8. Handayani R. Pengaruh terapi murottal alqur'an untuk penurunan nyeri persalinan dan kecemasan pada ibu bersalin kala I fase aktif. Bidan Prada: Jurnal Ilmiah Kebidanan 2014; 5(2) Edisi Desember 2014.

9. Hasto AI. Effect of listening Qur'an on pain postoperative caesarean section. 2014. Retrieved from http://www.arisaskowigi.com/?p=146

10. Hsieh AY, Tripp DA, Ji LJ. The influence of ethnic concordance and discordance on verbal reports and nonverbal behaviors of pain. Pain 2011; 152(9), 2016-2022.

11. Shakeri M. Comparison of Labor Outcomes in Physiological and Normal Delivery Methods. Researcher 2014; 6(6):14-17

12. Shakeri M. Effect of Physiologic Labor on Pain Intensity during Active Phase of Labor. Researcher 2014; 6(6):10-13

13. Shakeri, Molae, Choopani. The impact of mothers' group education on labor process. Researcher 2014;6(6):60-63

14. Sumira, Nirwana, Mato R. Factors affecting the duration of labor. E Journal Stikesnh, 2013; 3(3), 44-49. Retrieved from library.stikesnh.ac.id 